DOI https://doi.org/10.30525/978-9934-571-83-1-20

\title{
ФОРМУВАННЯ ОБ'ЄДНАНОЇ ТЕРИТОРІАЛЬНОЇ ГРОМАДИ ЯК ІНСТИТУТУ ГРОМАДЯНСЬКОГО СУСПІЛЬСТВА: ЄВРОПЕЙСЬКИЙ ДОСВІД ДЛЯ УКРАЇНИ
}

\section{Панчишин P. I.}

\section{ВСТУП}

Місцеве самоврядування гарантоване Європейською Хартією місцевого самоврядування ${ }^{1}$, а також Конституцією України ${ }^{2}$. Первинним суб'єктом місцевого самоврядування, основним носієм його функцій і повноважень $\epsilon$ територіальна громада села, селища, міста ${ }^{3}$. Саме тому формування спроможної територіальної громади як одного із важливих інститутів громадянського суспільства $є$ одним із завдань розбудови суверенної i незалежної, демократичної, соціальної, правової держави.

Спроможність територіальної громади зумовлена насамперед іiі можливістю вирішувати під власну відповідальність питання місцевого значення як безпосередньо, так і через утворені органи місцевого самоврядування. Така спроможність забезпечується за допомогою різних механізмів, зокрема правового, організаційного, фінансового характеру.

Разом із тим, визначаючи критерії спроможності територіальної громади, слід мати на увазі не тільки можливість через сформовані нею представницькі органи місцевого самоврядування вирішувати питання місцевого значення, але й здійснювати безпосередній та реальний вплив на прийняття управлінських та владних рішень органами державної влади та місцевого самоврядування. Такий вплив реалізується через різні форми безпосередньої демократії, які відповідно до Конституції України не обмежуються виборами та референдумами, а включають також й інші способи волевиявлення громадян.

Світовою практикою вироблено багато форм безпосередньої участі територіальної (об'єднаної) громади у здійсненні місцевого самоврядування. Причому, як показує досвід деяких європейських країн, ефективність здійснення місцевого самоврядування зумовлена саме

\footnotetext{
1 Європейська хартія місцевого самоврядування : Міжнародний документ від 15.10.1985. URL: https://zakon.rada.gov.ua/laws/show/994_036.

2 Конституція України : Основний Закон України від 28.06.1996 № 254к/96-BP. URL: https://zakon.rada.gov.ua/laws/show/254\%D0\%BA/96-\%D0\%B2\%D1\%80.

3 Про місцеве самоврядування в Україні : Закон України від 21.05.1997 № 280/97-BP. URL: https://zakon.rada.gov.ua/laws/show/280/97-\%D0\%B2\%D1\%80.
} 
активністю місцевого населення у процесі прийняття управлінських рішень на місцевому рівні, а рівень демократії в державі залежить, крім іншого, від гарантій реалізації права територіальної (об'єднаної) громади на участь у діяльності органів місцевого самоврядування.

У зв'язку з цим успішне завершення реформи децентралізації в Україні, визначення способів формування територіальної (об'єднаної) громади як одного 3 важливих інститутів громадянського суспільства потребує вивчення та застосування досвіду європейських країн, чому й присвячено цю наукову статтю.

\section{1. Об'сднана територіальна громада як інститут громадянського суспільства}

Територіальна (об’єднана) громада $€$ самостійним учасником муніципально-правових відносин, первинним суб'єктом місцевого самоврядування. Важливість тієї ролі, яку відіграє територіальна (об’єднана) громада у суспільстві та державі, іiї особливий муніципальноправовий статус дають підстави припустити належність територіальної (об’єднаної) громади до інститутів громадянського суспільства.

Подібна точка зору висловлюється багатьма науковцями, які, виходячи 3 тих чи інших критеріїв (ознак), обгрунтовують віднесення територіальної громади до інститутів громадянського суспільства.

Так, О. Свтушенко зазначає, що місцеве самоврядування - це система відносин, що складаються 3 приводу розподілу місцевої влади між політичними суб'єктами на місцевому рівні, де політичним центром виступають органи місцевого самоврядування, навколо яких діють місцеві партійні й громадські організації, засоби масової інформації, лобістські угруповання, політичні лідери тощо. Місцеве самоврядування, на думку науковця, як елемент політичної системи громадянського суспільства, який організовує діяльність людей зі здійснення контролю над ресурсами місцевого співтовариства, переданими йому державою й населенням, стає інститутом політичної системи суспільства, адже воно стає простором для спільного інтересу держави й громадянського суспільства ${ }^{4}$.

Своєю чергою О.Р. Сергєєва наводить такі аргументи на підтвердження концепції щодо віднесення місцевого самоврядування та його первинного суб'єкта до інститутів громадянського суспільства: 1) оскільки громадянське суспільство дистанційоване від держави, має свої цілі та завдання, відповідно, й місцеве самоврядування та його суб'єкти подібно до інститутів громадянського суспільства також відділені від органів

\footnotetext{
${ }^{4}$ Євтушенко О. Місцеве самоврядування - інститут громадянського суспільства та демократичної політичної системи. Українська національна ідея: реалії та перспективи розвитку. 2009. Вип. 21. С. 69.
} 
державної влади; 2) сучасне місцеве самоврядування, будучи формою самоорганізації населення, має ознаки як владного, так і суспільного інституту; 3) сучасні принципи та форми організації місцевого самоврядування $\epsilon$ результатом складного процесу пошуку компромісу, узгодження інтересів суспільства та держави; 4) місцеве самоврядування $\epsilon$ однією 3 форм демократії; 5) спроможне місцеве самоврядування формується у громадянському суспільстві на певному етапі його розвитку ${ }^{5}$.

Отже, територіальна (об'єднана) громада як первинний суб'єкт місцевого самоврядування характеризується всіма основними ознаками інституту громадянського суспільства, про що свідчить, зокрема, іiі особливе становище у правовідносинах з органами державної влади та місцевого самоврядування. Інакше кажучи, територіальна (об'єднана) громада має реальну можливість та встановлені міжнародними актами та Конституцією України гарантії брати участь в управлінні державними справами та самостійно і під власну відповідальність вирішувати питання місцевого значення.

Обгрунтовуючи наукову концепцію щодо віднесення місцевого самоврядування i, відповідно, територіальної (об'єднаної) громади як іiі первинного суб'єкта до інститутів громадянського суспільства, слід з'ясувати значення поняття «інститут громадянського суспільства».

Так, В.Ф. Погорілко розглядає громадянське суспільство як самоорганізовану і саморегульовану сферу публічно-правових відносин у державі, утворювану вільними і рівними індивідами та створеними ними об'єднаннями громадян, які функціонують, формуючи соціальний капітал та здійснюючи контроль за органами державної влади, служать підгрунтям демократії та визначальним чинником у розбудові правової держави. Тобто громадянське суспільство, на думку науковця, не може ототожнюватися 3 якимось одним суб'єктом публічно-правових відносин, оскільки ця категорія означає передусім систему суспільних відносин, які виникають, змінюються та припиняються між множиною їх різнопорядкових учасників ${ }^{6}$.

У науковій літературі наголошується на тому, що громадянське суспільство належить до основоположних цінностей Європейського Союзу (далі - СС) і розглядається як одна 3 ключових засад функціонування демократії. У грудні 2007 року було підписано Лісабонський договір ${ }^{8}$,

\footnotetext{
Сергєєва О.Р. Місцеве самоврядування у процесах демократизації суспільства в Україні. Економічний нобелівський вісник. 2014. № 1. С. 403.

${ }^{6}$ Погорілко В.Ф. Конституційне право України. Академічний курс : підручник. У 2 т. Т. 1. Київ : ТОВ «Видавництво «Юридична думка», 2006. 544 с.

7 Непоп Л. Політика Європейського Союзу щодо розвитку громадянського суспільства. Наукові записки. 2014. Вип. 2 (70). С. 242.

8 Договір про Свропейський Союз : Міжнародний документ від 07.02.1992. URL: http://zakon5.rada.gov.ua/laws/show/994_029.
} 
який став базовим документом, що визначає основи функціонування $\mathrm{CC}$. Метою цього документа було зробити Свросоюз ще більш демократичним, ефективним та здатним краще відповідати на сучасні виклики та загрози глобального світу. Серед ключових нововведень, запроваджених Лісабонським договором, стало, зокрема, запровадження так званої ініціативи європейських громадян - механізму, через який громадяни СС отримали можливість ініціювати винесення на розгляд інституцій $\mathrm{CC}$ питань, що мають суспільний інтерес.

Намагаючись слідувати світовим та насамперед європейським тенденціям, в Україні прийнято низку нормативно-правових актів, присвячених проблемам розвитку громадянського суспільства.

Так, одним 3 таких актів є Указ Президента України «Про сприяння розвитку громадянського суспільства в Україні» від 26 лютого 2016 р. № 68, в якому наголошується, що активне, впливове й розвинене громадянське суспільство $\epsilon$ важливим елементом будь-якої демократичної держави та відіграє одну з ключових ролей у впровадженні нагальних суспільних змін і належного врядування, в управлінні державними справами й вирішенні питань місцевого значення, розробці та реалізації ефективної державної політики в різних сферах, утвердженні відповідальної перед людиною правової держави, розв'язанні політичних, соціально-економічних і гуманітарних проблем 9 .

Таким чином, національний курс на розвиток інститутів громадянського суспільства зумовлений європейськими тенденціями демократизації суспільства, що передбачає розширення форм безпосередньої демократії, активізації залучення громадськості до участі у публічному управлінні. Одним із напрямів розвитку інститутів громадянського суспільства $\epsilon$ формування об'єднаної територіальної громади як спроможного суб'єкта здійснення місцевої публічної влади.

3 цього приводу варто зауважити, що традиційно у науковій літературі виділяють дві класичні концепції моделі взаємин центральної та місцевої влади: модель партнерства та агентську модель. Перша модель характерна для таких держав, як США, Швейцарія, Голландія, політична система яких формувалась знизу шляхом поступового об'єднання різних місцевих співтовариств, і розглядає відносини місцевих і центральних влад як відносини партнерів, що мають спільні цілі та надають необхідні послуги населенню. Натомість у межах агентської моделі відносини між центральними та місцевими владами розглядаються як відносини агента та

\footnotetext{
9 Про сприяння розвитку громадянського суспільства в Україні : Указ Президента України від 26.02.2016 № 68/2016. URL: http://zakon0.rada.gov.ua/laws/show/68/2016/paran20\#n20.
} 
принципала, тобто акцент зроблено на чільній ролі центру у відносинах 3 місцевим управлінням ${ }^{10}$.

Для вітчизняної форми організації публічної влади на центральному та місцевому рівнях більш характерною $є$ агентська модель взаємин цих двох видів влади, оскільки, хоча у Конституції України гарантується місцеве самоврядування, однак обсяг та межі повноважень, якими наділяються органи місцевого самоврядування, визначаються законами.

При цьому необхідно погодитись 3 думкою Ю.К. Маслова, який зазначає, що місцеве самоврядування є політичним інститутом, який водночас $є$ i інститутом публічної влади, і інститутом громадянського суспільства, які у сукупності формують специфічність та певну унікальність місцевого самоврядування як структурного елемента сучасних демократичних систем влади ${ }^{11}$.

Разом із тим необхідно зауважити, що для становлення територіальної (об'єднаної) громади як інституту громадянського суспільства мають бути утворені сприятливі політико-правові та організаційні умови, що узгоджується з концепцією стосовно того, що територіальна громада стає інститутом громадянського суспільства лише на певному етапі розвитку останнього.

Як зазначають у цьому зв'язку деякі науковці, в умовах початкового, неповного становлення демократичної, соціальної, правової державності розрив між інтересами територіальної спільноти та напрямами діяльності відособленого від суспільства апарату держави може бути найбільш очевидним, через що у співвідношенні держава - місцеве самоврядування на перший план замість вектора пошуку можливих шляхів їхньої взаємодії виходить проблема «захисту» самостійності місцевого самоврядування на випадок протистояння ${ }^{12}$.

Крім того, важливим $є$ подолання ментальної прірви у свідомості громадян між справами, що вирішуються кожним окремим пересічним жителем («свої» справи), і справами, що вирішуються на загальнодержавному рівні і сприймаються ним як політичні й абстрактні, до яких пересічному жителю майже нема діла, бо все одно він на них майже не впливає («чужі» справи) ${ }^{13}$. Тобто йдеться про внутрішню готовність громади займати активну позицію,

\footnotetext{
${ }^{10}$ Чапала Г.В. Місцеве самоврядування і громадянське суспільство - питання співвідношення. Форум права. 2012. № 4. С. 1002.

11 Маслов Ю.К. Місцеве самоврядування як структурний елемент системи влади сучасних країн Європи. Політологія. 2014. № 11(115). С. 104.

12 Чапала Г.В. Місцеве самоврядування і громадянське суспільство - питання співвідношення. Форум права. 2012. № 4. С. 1004.

13 Батанов О.В., Кравченко В.В. Місцеве самоврядування як інститут громадянського суспільства: муніципально-правові проблеми взаємодії та функціонування. Аспекти публічного правління. 2018. Том 6. № 6-7. С. 48.
} 
мати бажання та можливість брати участь у здійсненні місцевого самоврядування та брати на себе відповідальність за стан розвитку регіону.

Отже, слід констатувати, що територіальна (об'єднана) громада лише тоді може вважатися інститутом громадянського суспільства, коли у державі передбачені реальні та дієві гарантії самостійного здійснення громадами місцевого самоврядування, наявний механізм забезпечення безпосередньої участі територіальної громади у здійсненні публічного управління, а також готовності самих громад приймати на себе відповідальність за стан справ у відповідному регіоні.

\section{2. Форми прямої участі об'сднаної територіальної громади у здійсненні місцевого самоврядування}

Конституцією України гарантовано право громадян брати участь у публічному управлінні через вибори, референдуми та інші форми безпосередньої демократії. Тобто форми безпосередньої демократії $\epsilon$ необмеженими та включають можливість громадян брати участь у прийнятті управлінських рішень у будь-який спосіб, не заборонений Конституцією України.

Міністерством юстиції України у лютому 2011 року надано роз'яснення 3 приводу форм взаємодії держави 3 інститутами громадянського суспільства. Зокрема, зазначається, що така взаємодія здійснюється шляхом забезпечення участі інститутів громадянського суспільства у нормотворчій діяльності держави, яка забезпечується участю у розробленні та обговоренні проектів нормативно-правових актів; участю інститутів громадянського суспільства у правозастосовній та правоохоронній діяльності держави ${ }^{14}$.

При цьому деякі науковці виділяють такі форми участі інститутів громадянського суспільства у нормотворчому процесі:

- форми прямої участі: проведення консультацій $з$ громадськістю, участь у діяльності громадських рад при міністерствах, інших центральних та місцевих органах виконавчої влади, розробка та презентація власних пропозицій до законопроектів, подання електронних петицій та ін.;

- форми опосередкованої участі: подання конституційних скарг, адміністративних позовів щодо визнання незаконними та нечинними актів законодавства, громадський контроль та моніторинг виконання обіцянок, наданих владними суб'єктами, та ін.;

- радикальні форми: суспільний тиск, громадські акції протесту, громадська непокора;

\footnotetext{
${ }^{14}$ Взаємодія держави та інститутів громадянського суспільства : Роз'яснення Міністерства юстиції України від 03.02.2011. URL: http://search.ligazakon.ua/1_doc2.nsf/link1/MUS14895.html.
} 
- компромісні форми: публічне обговорення проблеми в ЗМІ або в мережі Інтернет, отримання коментарів експертів щодо законопроектів та ін. ${ }^{15}$.

У правозастосовній діяльності держави участь інститутів громадянського суспільства забезпечується шляхом:

- передачі повністю повноважень державних органів;

- передачі частково повноважень державних органів;

- громадського контролю ${ }^{16}$.

Таким чином, у теорії права вироблено цілу систему форм безпосередньої участі інститутів громадянського суспільства у здійсненні влади на державному та місцевому рівнях, реалізація яких у практичній площині потребує належного правового забезпечення. 3 огляду на це, справедливо зазначити, що такі форми безпосередньої участі інститутів громадянського суспільства у здійсненні публічного управління, як громадський контроль, публічне обговорення законопроектів та деякі інші, вкрай рідко демонструють на практиці високу ефективність. Причиною цьому $\epsilon$ насамперед відсутність правового механізму забезпечення реального впливу інститутів громадянського суспільства на суб'єктів публічної влади та рішення, що ними приймаються, через названі форми прямої демократії.

Говорячи про можливі форми прямої участі територіальної (об'єднаної) громади у здійсненні місцевого самоврядування, необхідно звернутися до аналізу положень Закону України «Про місцеве самоврядування в Україні» ${ }^{17}$, яким передбачено такі 3 них:

1. Місцеві вибори - основна форма прямої участі мешканців відповідної громади у здійсненні вибору представницьких органів місцевого самоврядування (ст. 10).

2. Місцевий референдум є формою вирішення територіальною громадою питань місцевого значення шляхом прямого волевиявлення (ст. 7). Разом із тим механізм здійснення цієї форми прямої участі громади у вирішенні питань місцевого значення наразі відсутній, внаслідок чого на практиці практично не застосовується. Наприклад, у 2014 р. Центральна виборча комісія не дала змогу провести місцевий референдум у м. Києві, обгрунтувавши свою відмову тим, що в чинному законодавстві України не прописано процедуру проведення місцевих референдумів ${ }^{18}$.

\footnotetext{
15 Берназюк Я.О. Форми участі інститутів громадянського суспільства у нормотворчому процесі. Конституційно-правові академічні студії. 2017. Вип. 1. С. 48.

16 Взаємодія держави та інститутів громадянського суспільства : Роз'яснення Міністерства юстиції України від 03.02.2011. URL: http://search.ligazakon.ua/1_doc2.nsf/link1/MUS14895.html.

17 Про місцеве самоврядування в Україні : Закон України від 21.05.1997 № 280/97-BP. URL: https://zakon.rada.gov.ua/laws/show/280/97-\%D0\%B2\%D1\%80.

18 ЦВК заблокувала проведення місцевих референдумів. Украӥнська правда. 2014. URL: http://www.pravda.com.ua/news/2014/02/18/7014215/.
} 
3. Загальні збори громадян за місцем проживання $\epsilon$ формою їхньої безпосередньої участі у вирішенні питань місцевого значення (ст. 8). Загальні збори можуть висувати місцеві ініціативи, тобто ініціювати розгляд у раді (в порядку місцевої ініціативи) будь-якого питання, віднесеного до відання місцевого самоврядування (ст. 9), включаючи питання дострокового припинення повноважень представницьких органів місцевого самоврядування.

4. Громадські слухання. Територіальна громада має право проводити громадські слухання - зустрічатися 3 депутатами відповідної ради та посадовими особами місцевого самоврядування, під час яких члени територіальної громади можуть заслуховувати їх, порушувати питання та вносити пропозиції щодо питань місцевого значення, що належать до відання місцевого самоврядування (ст. 13).

Крім того, відповідно до Закону України «Про засади державної регуляторної політики у сфері господарської діяльності» територіальна (об'єднана) громада має право брати безпосередню участь під час розроблення та прийняття регуляторних актів.

Так, одним із принципів прийняття регуляторних актів, визначених вказаним Законом, $є$ принцип прозорості та врахування громадської думки, що означає відкритість для фізичних та юридичних осіб, їхніх об'єднань дій регуляторних органів на всіх етапах їхньої регуляторної діяльності, обов'язковий розгляд регуляторними органами ініціатив, зауважень та пропозицій, наданих у встановленому законом порядку фізичними та юридичними особами, їхніми об'єднаннями, обов'язковість і своєчасність доведення прийнятих регуляторних актів до відома фізичних та юридичних осіб, їхніх об'єднань, інформування громадськості про здійснення регуляторної діяльності ${ }^{19}$.

При цьому недотримання вказаного принципу, зокрема процедури врахування громадської думки під час прийняття регуляторних актів, може бути підставою для визнання протиправними та скасування відповідних актів органів місцевого самоврядування ${ }^{20}$.

Також згідно $з$ положеннями Закону України «Про засади державної регуляторної політики у сфері господарської діяльності», громадяни, суб'єкти господарювання, їхні об'єднання та наукові установи, а також консультативно-дорадчі органи, що створені при органах державної влади та органах місцевого самоврядування і представляють інтереси громадян та суб'єктів господарювання, мають право:

\footnotetext{
${ }^{19}$ Про засади державної регуляторної політики у сфері господарської діяльності : Закон України від 11.09.2003 № 1160-IV. URL: https://zakon.rada.gov.ua/laws/show/1160-15.

20 Постанова Верховного Суду від 14 серпня 2018 року у справі № 359/6814/17. URL: http://www.reyestr.court.gov.ua/Review/75906258.
} 
подавати до регуляторних органів пропозиції про необхідність підготовки проектів регуляторних актів, а також про необхідність їх перегляду;

у випадках, передбачених законодавством, брати участь у розробці проектів регуляторних актів;

подавати зауваження та пропозиції щодо оприлюднених проектів регуляторних актів, брати участь у відкритих обговореннях питань, пов'язаних $з$ регуляторною діяльністю;

самостійно готувати аналіз регуляторного впливу проектів регуляторних актів тощо ${ }^{21}$.

Таким чином, участь територіальної (об’єднаної) громади у здійсненні місцевого самоврядування не обмежується місцевими виборами, а включає й низку інших форм прямої участі. Водночас для застосування деяких із визначених вище форм на практиці необхідно прийняти низку законодавчих актів, що визначатимуть не тільки порядок прямої участі територіальної (об’єднаної) громади у здійсненні місцевого самоврядування, але й механізм забезпечення такої участі (гарантії).

Про це, зокрема, йдеться в Указі Президента України «Про сприяння розвитку громадянського суспільства в Україні». Так, перспективами унормування на законодавчому рівні визначені:

- порядок проведення органами місцевого самоврядування консультацій 3 громадськістю щодо проектів нормативно-правових актів під час їх розроблення зі встановленням вичерпного переліку випадків, коли такі консультації не проводяться, та механізму запобігання порушенню вимог щодо обов'язковості таких консультацій;

- порядок ініціювання та проведення місцевих референдумів;

- порядок ініціювання, проведення загальних зборів (конференцій) членів територіальної громади за місцем проживання та реалізації їх рішень;

- обов'язковість затвердження у кожній територіальній громаді іiі статуту, що визначає, зокрема, порядки організації громадських слухань, внесення місцевої ініціативи та реалізації інших форм демократії участі;

- сприяння запровадженню на рівні органів місцевого самоврядування публічних консультацій з громадськістю, громадської експертизи їхньої діяльності та діяльності їхніх виконавчих органів, посадових осіб, комунальних підприємств, організацій та установ;

\footnotetext{
${ }^{21}$ Про засади державної регуляторної політики у сфері господарської діяльності : Закон України від 11.09.2003 № 1160-IV. URL: https://zakon.rada.gov.ua/laws/show/1160-15.
} 
- сприяння запровадженню обов'язкових публічних консультацій у процесі підготовки проектів Державного бюджету України та місцевих бюджетів тощо 22 .

\section{3. Реформа децентралізації: проблеми здійснення в Україні та зарубіжний досвід їх подолання}

У процесі становлення територіальної (об'єднаної) громади як інституту громадянського суспільства неабияку роль відіграє реформа децентралізації, одним із ключових завдань якої є формування спроможної об'єднаної територіальної громади.

Разом із тим, як зауважують деякі науковці, уже проявляються певні недоліки під час реформи. Насамперед указують на недостатній професіоналізм управлінців на всіх рівнях виконавчої влади, їх неготовність до участі у творчому процесі, яким є реформа, бо насправді ефективних реформ за час незалежності в Україні було небагато. Крім того, деякі вчені також указують на неспроможність української системи влади оперативно впроваджувати необхідні зміни у чинній нормативноправовій базі. Проблемною вбачається i можливість внесення конституційних змін, без яких повноцінна адміністративно-територіальна реформа в Україні не відбудеться ${ }^{23}$.

Для реалізації одного 3 головних завдань реформи децентралізації (формування спроможної територіальної громади) було обрано спосіб, який показав свою високу ефективність у багатьох країнах Свропи, зокрема, йдеться про об'єднання незначних за обсягом, неспроможних у фінансовому та ресурсному відношеннях територіальних громад та надання їм самостійності у вирішенні питань місцевого значення (розширення повноважень).

Так, досвід таких країн Європи, як Польща, Болгарія, Естонія, Латвія та ін., свідчить про те, що спроможність громади значною мірою залежить від мінімально визначеної кількості мешканців відповідної адміністративнотериторіальної одиниці. Зокрема, у цих країнах загальновизнаним $\epsilon$ стандарт, що територія локальної спільноти мусить мати достатній потенціал для надання громадських послуг і їі межі можуть бути змінені лише рішенням національного парламенту, у Болгарії $\epsilon$ норма, що мінімальна кількість жителів має становити 6 тис. осіб, в Естонії - 3,5 тис., у Латвії - 5 тис., в Угорщині - 3 тис. осіб ${ }^{24}$.

\footnotetext{
22 Про сприяння розвитку громадянського суспільства в Україні : Указ Президента України від 26.02.2016 № 68/2016. URL: https://zakon.rada.gov.ua/laws/show/68/2016.

${ }^{23}$ Федірко Б.О. Сучасний стан та напрями реформування системи місцевого самоврядування в Україні. Територіальний розвиток та регіональна економіка. 2015. Вип. 6 (115). С. 21.

24 Матяж С.В. Свропейський досвід розвитку та функціонування інститутів громадянського суспільства. Наукові пращі. Політологія. 2013. Випуск 218. Том 230. С. 29.
} 
Намагаючись слідувати подібній європейській практиці, народними депутатами та іншими суб'єктами права законодавчої ініціативи було розроблено та подано на розгляд Верховної Ради України низку законопроектів, якими, зокрема, визначено механізм об'єднання громад ${ }^{25}$.

Аналізуючи положення цих законопроектів, деякі науковці зазначають, що фактично пропозиції авторів зводяться до двох новацій: перша - це злиття декількох районів в один, великий; друга - це злиття районних рад цих районів в одну, об'єднану. При цьому основним недоліком та проблемою цих законопроектів, на думку дослідників, $\epsilon$ те, що таке злиття робиться в абсолютно механістичний спосіб, при цьому несформульовано принципи та критерії злиття територій районів, а питання відповідності формування нових рад виборчому законодавству взагалі випадає 3 поля зору ініціаторів процесу ${ }^{26}$.

Друге питання, яке постає за механічного злиття територій районів: наскільки раціонально сформовані наявні райони та якими виявляться нові, що тільки пропонується створити. На прикладі Херсонської області акцентується увага на значній відмінності між районами за розміром та населенням ${ }^{27}$.

Погоджуючись загалом із наведеними зауваженнями, варто зазначити, що законодавцю було б доцільно звернутися й до іншого (крім укрупнення населення та території адміністративної одиниці) позитивного досвіду деяких країн у сфері формування територіальної (об’єднаної) громади як інституту громадянського суспільства.

Приміром, Т.О. Астапова пропонує такі найважливіші заходи щодо зміцнення взаємодії місцевої влади і населення: публікація щорічних звітів про свою діяльність для забезпечення прозорості дій місцевих органів влади; сприяння розвитку волонтерських рухів; моральне і матеріальне заохочення ініціативних громадян; розвиток співпраці між громадськими організаціями й організаціями місцевих підприємців; створення добровільних союзів активістів на підтримку політики, що проводиться

\footnotetext{
25 Про внесення змін до Закону України «Про добровільне об'єднання територіальних громад» щодо добровільного приєднання територіальних громад сіл, селищ до територіальних громад міст республіканського Автономної Республіки Крим, обласного значення : проект Закону від 18.05.2017, реєстр № 6466. URL: http://w1.c1.rada.gov.ua/pls/zweb2/webproc4_1?pf3511=61814.

Про порядок утворення, ліквідації, встановлення і зміни меж районів: проект Закону від 22.06.2017, peєстр. № 6636. URL: http://w1.c1.rada.gov.ua/pls/zweb2/webproc4_1?pf3511=62118.

${ }^{26}$ Сергієнко О. Підходи до вирішення питань адміністративно-територіального устрою та проблем самоврядування районного рівня на прикладі Херсонської області: Інститут громадянського суспільства. 2019. URL: https://www.csi.org.ua/detsentralizatsiya-v-ukrayini-vid-monitoryngu-do-reaguvannya/na-prykladihersonskoyi-oblasti/.

27 Сергієнко О. Підходи до вирішення питань адміністративно-територіального устрою та проблем самоврядування районного рівня на прикладі Херсонської області: Інститут громадянського суспільства. 2019. URL: https://www.csi.org.ua/detsentralizatsiya-v-ukrayini-vid-monitoryngu-do-reaguvannya/na-prykladihersonskoyi-oblasti/.
} 
місцевою владою; створення спеціалізованих комп'ютерних систем спілкування 3 мешканцями території; використання сучасних інформаційних технологій, зокрема електронного врядування ${ }^{28}$.

Своєю чергою О.В. Батанов та В.В. Кравченко пропонують за прикладом деяких європейських держав запровадити інститут муніципальних омбудсменів, що, на думку науковців, дало би змогу ліквідувати наявні прогалини у сфері функціонування механізмів захисту прав людини, що, з одного боку, безумовно, мало би позитивний вплив на ефективне здійснення функцій не лише місцевого самоврядування, а й громадянського суспільства, а 3 іншого - не лише доповнило б наявну систему гарантій прав громадян, але і стало би новим органом, який забезпечує жителям - членам територіальних громад - ще один правозахисний канал у випадках порушення або обмеження їхніх прав ${ }^{29}$.

Необхідно підтримати пропозицію науковців, оскільки запровадження посади подібної до місцевого омбудсмена, певною мірою дало би змогу вирішити, крім іншого, проблему забезпечення виконання рішень загальних зборів громади або інших обов'язкових рішень, використовуючи позасудові механізми впливу на органи місцевого самоврядування.

При цьому велике значення має розвиток засад місцевої демократії, адже без наділення територіальної (об'єднаної) громади реальними повноваженнями у цій сфері неможливо вести мову про ії̈ становлення як інституту громадянського суспільства.

3 цього приводу слушною видається думка С.В. Матяж щодо доцільності на підставі досвіду країн Центральної Свропи запровадити в Україні практику формування допоміжних органів самоврядування, які створюються у підпорядкованих територіальних одиницях єдиних територіальних громад (населених пунктах, сільських округах, районах); органів територіального громадського самоврядування; громадянських ініціатив, які вирішують локальні проблеми, пов'язані насамперед із захистом території від будівництва небажаних виробничих та інфраструктурних об’єктів, благоустроєм громад, дозвіллям населення, підвищенням інвестиційного іміджу спільнот ${ }^{30}$.

Разом із тим деякі пропозиції, розроблені на підставі зарубіжного досвіду, видаються не цілком підходящими для України. Зокрема, П.В. Ворона пропонує в Україні створити єдиний державний орган, що

\footnotetext{
28 Астапова Т.О. Адаптація зарубіжного досвіду реформування діяльності органів місцевого самоврядування в Україні : автореф. дис. канд. наук з держ. управління : спец. 25.00.04. Харків, 2010. С. 11.

29 Батанов О.В., Кравченко В.В. Місцеве самоврядування як інститут громадянського суспільства: муніципально-правові проблеми взаємодії та функціонування. Аспекти публічного правління. 2018. Том 6. № 6-7. С. 49-50.

30 Матяж С.В. Свропейський досвід розвитку та функціонування інститутів громадянського суспільства. Наукові пращуі. Політологія. 2013. Випуск 218. Том 230. С. 29.
} 
здійснюватиме контроль за діяльністю органів самоврядування, обгрунтовуючи таку необхідність тим, що розмежування повноважень між радами різних рівнів та радами та обласними, районними державними адміністраціями - вимога часу ${ }^{31}$. Однак таку пропозицію слід оцінювати досить критично, оскільки утворення чергового державного органу, який здійснюватиме контроль за діяльністю органів місцевого самоврядування, навряд чи посилить самостійність та відповідальність територіальних громад та зменшить рівень корумпованості місцевої влади.

\section{ВИСНОВКИ}

Таким чином, на підставі проведеного дослідження можна зробити такі узагальнюючі висновки.

1. Ознаками територіальної (об'єднаної) громади як інституту громадянського суспільства $€$ те, що: 1) вона є відмінним та відокремленим від державної влади відносно організаційно-інституційним утворенням, яке об'єднує мешканців території населеного пункту (декількох населених пунктів); 2) вона $\epsilon$ активним учасником публічного управління на місцевому рівні, носієм місцевої влади; 3) вона володіє реальною здатністю та бажанням під власну відповідальність здійснювати публічну владу на місцевому рівні, вирішувати питання місцевого значення; 4) у держави наявний правовий механізм забезпечення участі територіальної (об’єднаної) громади у здійсненні публічного управління як на загальнодержавному, так i місцевому рівнях; 5) вона є частиною політичної системи держави, становить один з їі рівнів, оскільки бере безпосередню участь у формуванні представницьких органів публічного управління на місцевому рівні та здатна здійснювати реальний вплив на політичну організацію у державі.

2. Головними проблемами становлення територіальної (об'єднаної) громади як інституту громадянського суспільства $€: 1)$ нерозробленість на законодавчому рівні механізмів забезпечення прямої участі об'єднаної територіальної громади у здійсненні місцевого самоврядування, зокрема відсутність відповідальності за неврахування обов'язкових рішень громади під час прийняття нормативно-правових актів органів державної влади та місцевого самоврядування; 2) пасивність та правовий нігілізм мешканців територіальної громади, що спричинене передусім невірою у можливості реального впливу громади на публічне управління; 3) непослідовність прийняття деяких законодавчих актів у сфері об'єднання територіальних громад, механізація цього процесу без урахування особливостей та реальних потреб відповідних регіонів.

\footnotetext{
31 Ворона П.В. Місцеве самоврядування України в контексті розвитку представницької влади : монографія. Полтава : ПУЕТ, 2012. С. 132.
} 
3. На підставі позитивного європейського досвіду у сфері формування об'єднаної територіальної громади як інституту громадянського суспільства можна визначити такі способи подальшого ії розвитку: 1) розробити національну стратегію формування нового іміджу територіальної (об’єднаної) громади як активного та відповідального суб'єкта місцевого самоврядування; 2) запровадити інститут муніципально-правової відповідальності органів місцевого самоврядування та інші механізми позасудового забезпечення виконання управлінських рішень територіальної (об’єднаної) громади; 3) прийняти закон про місцевий референдум та інші форми прямої участі територіальної (об'єднаної) громади у здійсненні місцевого самоврядування.

\section{АНОТАЦІЯ}

Статтю присвячено висвітленню основних проблемних питань становлення об'єднаної територіальної громади як інституту громадянського суспільства в Україні. На підставі дослідження наукових концепцій обгрунтовано ознаки територіальної (об’єднаної) громади як інституту громадянського суспільства. Визначено форми участі територіальної (об'єднаної) громади як інституту громадянського суспільства у здійсненні місцевого самоврядування. Охарактеризовано хід здійснення муніципальної реформи децентралізації, виявлено окремі проблемні питання, що виникають у процесі ії здійснення. Аргументовано переваги безпосередньої участі об'єднаної територіальної громади у здійсненні місцевого самоврядування. Досліджено досвід деяких зарубіжних країн у сфері формування об'єднаної територіальної громади як інституту громадянського суспільства. На підставі вивчення такого досвіду розроблено пропозиції щодо подальшого формування в Україні об'єднаної територіальної громади як спроможного інституту громадянського суспільства.

\section{ЛІТЕРАТУРА}

1. Астапова Т.О. Адаптація зарубіжного досвіду реформування діяльності органів місцевого самоврядування в Україні : автореф. дис. канд. наук з держ. управління : спец. 25.00.04. Харків, 2010. 18 с.

2. Батанов О.В., Кравченко В.В. Місцеве самоврядування як інститут громадянського суспільства: муніципально-правові проблеми взаємодії та функціонування. Аспекти публічного правління. 2018. Том 6. № 6-7. C. $45-53$.

3. Берназюк Я.О. Форми участі інститутів громадянського суспільства у нормотворчому процесі. Конституиійно-правові академічні студіï. 2017. Вип. 1. С. 43-51. 
4. Взаємодія держави та інститутів громадянського суспільства : Роз'яснення Міністерства юстиції України від 03.02.2011. URL: http://search.ligazakon.ua/l_doc2.nsf/link1/MUS14895.html.

5. Ворона П.В. Місцеве самоврядування України в контексті розвитку представницької влади : монографія. Полтава : ПУЕТ, 2012. 187 с.

6. Договір про Свропейський Союз : Міжнародний документ від 07.02.1992. URL: http://zakon5.rada.gov.ua/laws/show/994_029.

7. Свропейська хартія місцевого самоврядування : Міжнародний документ від 15.10.1985. URL: https://zakon.rada.gov.ua/laws/show/994_036.

8. Свтушенко О. Місцеве самоврядування - інститут громадянського суспільства та демократичної політичної системи. Українська національна ідея: реалії та перспективи розвитку. 2009. Вип. 21. С. 66-70.

9. Конституція України : Основний Закон України від 28.06.1996 № 254к/96-BP. URL: https://zakon.rada.gov.ua/laws/show/254\%D0\%BA/96$\% \mathrm{D} 0 \% \mathrm{~B} 2 \% \mathrm{D} 1 \% 80$.

10. Маслов Ю.К. Місцеве самоврядування як структурний елемент системи влади сучасних країн Європи. Політологія. 2014. № 11(115). C. $101-105$.

11. Матяж С.В. Європейський досвід розвитку та функціонування інститутів громадянського суспільства. Наукові пращі. Політологія. 2013. Випуск 218. Том 230. С. 28-31.

12. Непоп Л. Політика Свропейського Союзу щодо розвитку громадянського суспільства. Наукові записки. 2014. Вип. 2 (70). C. $240-245$.

13. Павлюк К.В., Іголкін І.В. Особливості соціоструктурних взаємодій громадянського суспільства і держави в країнах Західної Європи. Збірник наукових праџь Національного університету державної податкової служби України. 2011. № 1. С. 418-428.

14. Погорілко В.Ф. Конституційне право України. Академічний курс : підручник. У 2 т. Т. 1. Київ : ТОВ «Видавництво «Юридична думка», 2006. $544 \mathrm{c}$.

15. Постанова Верховного Суду від 14 серпня 2018 року у справі № 359/6814/17. URL : http://www.reyestr.court.gov.ua/Review/75906258.

16. Про внесення змін до Закону України «Про добровільне об'єднання територіальних громад» щодо добровільного приєднання територіальних громад сіл, селищ до територіальних громад міст республіканського Автономної Республіки Крим, обласного значення : проект Закону від 18.05.2017, реєстр № 6466. URL: http://w1.c1.rada.gov.ua/pls/zweb2/ webproc4_1?pf3511=61814. 
17. Про засади державної регуляторної політики у сфері господарської діяльності : Закон України від 11.09.2003 № 1160-IV. URL: https://zakon.rada.gov.ua/laws/show/1160-15.

18. Про місцеве самоврядування в Україні : Закон України від 21.05.1997 № 280/97-BP. URL: https://zakon.rada.gov.ua/laws/show/280/97$\% \mathrm{D} 0 \% \mathrm{~B} 2 \% \mathrm{D} 1 \% 80$.

19. Про порядок утворення, ліквідації, встановлення і зміни меж районів : проект Закону від 22.06.2017, реєстр. № 6636. URL: http://w1.c1.rada.gov.ua/pls/zweb2/webproc4_1?pf3511=62118.

20. Про сприяння розвитку громадянського суспільства в Україні : Указ Президента України від 26.02.2016 № 68/2016. URL: https://zakon.rada.gov.ua/laws/show/68/2016.

21. Сергєєва О.Р. Місцеве самоврядування у процесах демократизації суспільства в Україні. Економічний нобелівський вісник. 2014. № 1. C. $400-406$.

22. Сергієнко О. Підходи до вирішення питань адміністративнотериторіального устрою та проблем самоврядування районного рівня на прикладі Херсонської області: Інститут громадянського суспільства. 2019. URL: https://www.csi.org.ua/detsentralizatsiya-v-ukrayini-vid-monitoryngu-doreaguvannya/na-prykladi-hersonskoyi-oblasti/.

23. ЦВК заблокувала проведення місцевих референдумів. Украӥнська правда. 2014. URL : http://www.pravda.com.ua/news/2014/02/18/7014215/.

24. Федірко Б.О. Сучасний стан та напрями реформування системи місцевого самоврядування в Україні. Територіальний розвиток та регіональна економіка. 2015. Вип. 6 (115). С. 18-22.

25. Чапала Г.В. Місцеве самоврядування і громадянське суспільство питання співвідношення. Форум права. 2012. № 4. С. 1000-1005.

\section{Information about author:} Panchishin R. I., Candidate of Law,

Doctoral Candidate of the Chair of Constitutional Law and Comparative Law Uzhgorod National University 3, Narodna Sq., Uzhhorod, Ukraine 